\title{
現地河川での植生浄化水路実験による水質浄化効果と 付着藻類·プランクトンの動態について
}

ON THE PURIFICATION EFFECTS BASED ON THE BIOLOGICAL CHARACTERISTICS OF EPIPHYTIC ALGAE AND PLANKTON IN RIVER WATER BY ON-SITE WETLAND EXPERIMENT

\author{
津田 $\quad$ 将行 $^{1} \cdot$ 尾島 $\quad$ 勝 $^{2}$ \\ Masayuki TSUDA and Masaru OJIMA \\ ${ }^{1}$ 正会員 博 (工） 福山大学助手 工学部建設環境工学科（广729-0292 広島県福山市学園町 1 番地三蔵) \\ 2 フェロー会員 工博 福山大学教授 工学部建設環境工学科 （テ729-0292 広島県福山市学園町 1 番地三蔵)
}

\begin{abstract}
The large-scale experimental channels were constructed in the Takaya river course which a branch of the Ashida river, in Fukuyama-city. This study is one of the experiments by plants purification method. In this study, three channels were used for purification tests by plants such as reed, sweet yellow flag and another channel which called a control channel were paved by nothing. The polluted river water is conducted into 3-plants channels by pumping during about 6 months, from May to October, 2003. The purification effects were estimated by several items of water quality and biological. At three points so as upstream, midstream and downstream in the three experimental channels. In this paper, items such as characteristics of BOD, nitrogen and phosphorus were especially considered from both particle component and the dissolved component. The biological investigations were considered from 3-kinds investigation items such as epiphytic algae, phytoplankton and zooplankton were evaluated due to those population density, appearance genera, etc.
\end{abstract}

Key Words : plants purification method, purification of water quality, epiphytic algae, phytoplankton, zooplankton

\section{1. はじめに}

植生浄化法は、植物を配した浄化施設に污濁した河川 水学導さ、その施設内での沈殿、土壌への吸着、植物に よる吸収・分解などにより污濁物質を除去するものであ る。また植生浄化法は省エネルギ一的に施工・維持管理で きる他、風を減衰させ底泥の巻上げの抑制、生物群の棲 息・生育の場を提供(日照の妨げによる植物プランクトン の発生の抑制、生物膜による吸収・分解) などの浄化の環 境を整える機能もあるが、土袞や植物体から系への回帰 などの負の効果もある1)、2)。

植生浄化法に関する既往の研究内容では、水質浄化能 力、栄養塩(窒素やリン)の吸収量や吸収速度、沈殿促進効 果、風速の減衰効果および光遮蔽効果、根からの酸素の 放出、ヨシの窒素除去に及ぼす効果、ヨシの生長の数值 モデルを用いた定量評価などが挙げられる。しかしなが ら、植生浄化法には生物群の棲息·生育の場を提供してい
るが、その生物群に関してはほとんど研究されていない。 本研究では実河川に設けた大型実験水路において植生 浄化実験を行う。本研究では抽水植物を選び、他，の施設 でも多く実験されているヨシとホテイアオイよりも約 1.9 倍の T-P 浄化能を有する ${ }^{3)}$ キショウブを用いる。水質 浄化能と水路環境への影響を水路に棲息寸る付着藻類、 植物プランクトン、及び動物プランクトンの生物量の変 化や種の遷移過程を把握し、流量、水温、水質指標の変 化と併せて水質净化効果を総合的に評価する。

\section{2. 実験および調査概要}

実験水路は芦田川左支川高屋川の河道内左岸に、既設 の全長 $60 \mathrm{~m}$ 、幅 $1 \mathrm{~m}$ 、高さ $1 \mathrm{~m}$ の防水コンクリート製(水 路勾配: 約 1/1200) が 3 水路ある。各水路間は $1 \mathrm{~m}$ となっ ており図-1 は実験水路概略図である。図-2 は実験水路を 上流側から下流側に全景を写したものである。図-2に示 


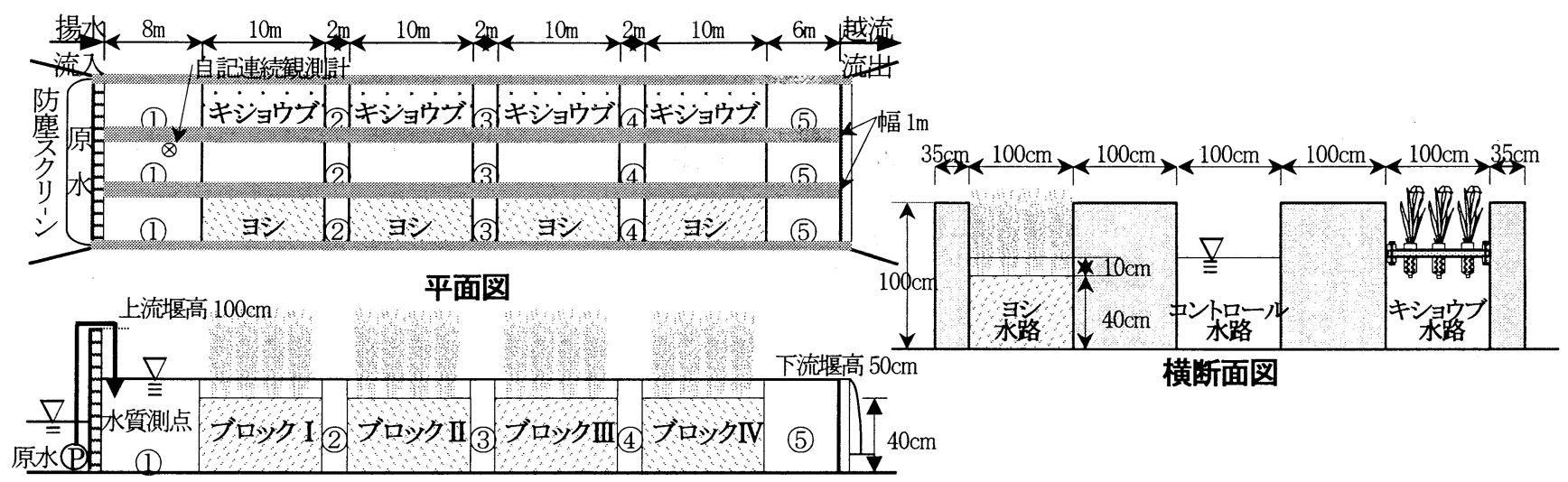

継断面図

図-1＼cjkstart防水コンクリート製実験水路概略図

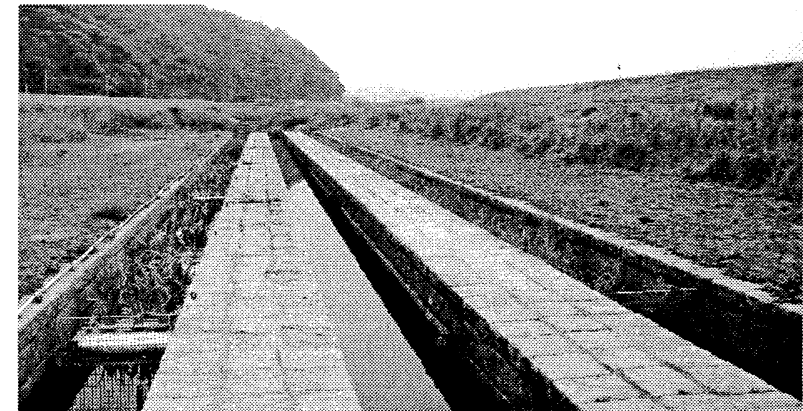

図-2＼cjkstart実験水路(上流功下流を撮影)

すように、岸側をキショウブ水路、川側をヨシ水路とし、 中央は無植栽の等量通水のみのコントロール水路とした。 ヨシは現地河川砂州の砂質土を $10 \mathrm{~m} \times 1 \mathrm{~m}$ の移植 4 ブ ロックに厚さ $40 \mathrm{~cm}$ で敷き、 $5 \sim 10$ 本を 1 株として、 $1 \mathrm{~m}^{2}$ 当り $5 \sim 8$ 株、 1 ブロック当り $70 \sim 80$ 株を植え付けた。

キショウブは図-3 に示した発砲スチロール $(90 \mathrm{~cm} \times$ $300 \mathrm{~cm}$ 、厚さ $10 \mathrm{~cm})$ を $6 \mathrm{~cm} \times 6 \mathrm{~cm}$ の角材フレームで周囲 を補強し、図のように穴を開け、ペットボトルを利用し た植生鉢に 1 個体ずつ植付け水面に浮かせ、1 ン゙ロック 3 連のポンツーンをピアノ線で水路壁に固定した。したが って、1ブロックあたり 45 株(球根)である。

実験期間は 2003 年 5 月 6 日から 10 月 23 日までの約 170 日間、水中ポンプにより各水路に $1.7 \mathrm{~m}^{3} / \mathrm{hr}(=28.30$ /min)を流入させ、連続通水実験を行った。

水質分析の採水は、植物の生育を考慮し、植物が最も 生育寸るであろう 5 月と 6 月は 5 月 22 日から毎週 1 回、 7 月から 10 月は 3 週間に 1 回行った。

計測·採水場所は各水路の水質観測点(原水、(1)～(5)）と し、現地で氷温、 $\mathrm{pH} 、 \mathrm{DO}$ 、電気伝導度、濁度を計測、 採水試料は実験室で $\mathrm{SS} 、 \mathrm{BOD} 、 \mathrm{D}-\mathrm{BOD} 、 \mathrm{COD} \mathrm{Cr} 、 \mathrm{~T}-\mathrm{N}$ 、 $\mathrm{NO}_{3}-\mathrm{N} 、 \mathrm{NO}_{2}-\mathrm{N} 、 \mathrm{NH}_{4}-\mathrm{N} 、 \mathrm{~T}-\mathrm{P} 、 \mathrm{D} . \mathrm{T}-\mathrm{P}$ を分析した。

生物調查は通水 1 ケ月後 $(6$ 月 5 日)、 3 ケ月後 $(8$ 月 11 日)、5 ケ月後(10月 23 日)に付着藻類、植物プランクトン 及び動物プランクトン調査を行った。調查測点は各水路 の測点(1)、測点(3)、測点(5)の合計 9 測点である。調査方 法は、付着藻類は各測点で、水路左岸側の水深約 $10 \mathrm{~cm}$

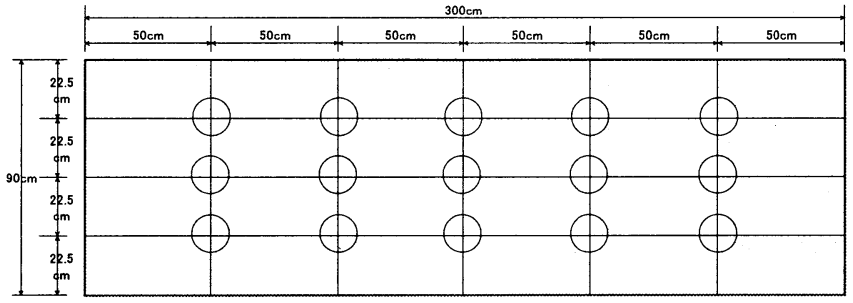

図-3 キショウブのポンツーンと植生鉢

あたりの水路壁面 $10 \mathrm{~cm} \times 10 \mathrm{~cm}$ 内を金ブラシで強く擦り 落とし採取し、杭归ン(5\%)で固定し、その一部を酸処理、 珪藻同定用試料とした。植物プランクトンは各測点で $2 \ell$ 採水し、机洲次\%)固定し、付着藻類と同様の処理を行い、 種の同定·計数を行った。動物プランクトンは 150 lをプ ランクトンネット(目合 $100 \mu \mathrm{m}$ ) で濃縮後、栤归 (5\%)固 定し、種の同定·計数を行った。これらの生物調查は侏日 本総合科学に委託した。

\section{3. 自記連続観測データによる水路流況}

コントロール水路の測点(1に、圧力式水位計を設置し、 通水開始した翌日の 5 月 7 日より 1 時間毎に水位連続観 測を行った。前述したように実験水路の平常水位は下流 堰高によって約 $0.5 \mathrm{~m}$ に制御されている。しかし実験水路 は河道敷内にあるため、強い降雨時には高濁水出水の影 響を直接受ける。図中の水路水位が $0.5 \mathrm{~m}$ から $1 \mathrm{~m}$ までは 河川水が水路下流堰板を超えて逆流している状態であり、 水路水位が $1 \mathrm{~m}$ 以上は河川水が水路上流堰板を越え、実 験水路は完全に冠水状態である。残念ながら水位連続観 測計は 9 月 9 日に故障してしまった。そのため 9 月 9 日 以降については、9月 8 日までの実験水路水位データの 下流堰高を超えた時の水位と、その時の実験水路より約 $1 \mathrm{~km}$ 上流にある国土交通省の御幸流量観測所の河川の時 間水位データに基づいて、相関式を求めて補完した。

図-4には 1 時間毎の実験水路水位デー夕(計算値) と対 象域上流部(神辺)の時間雨量值を示す。月別の冠水時間 と出水履歴は、 5 月は 14 時間と 6 時間の 2 回、 6 月は各 


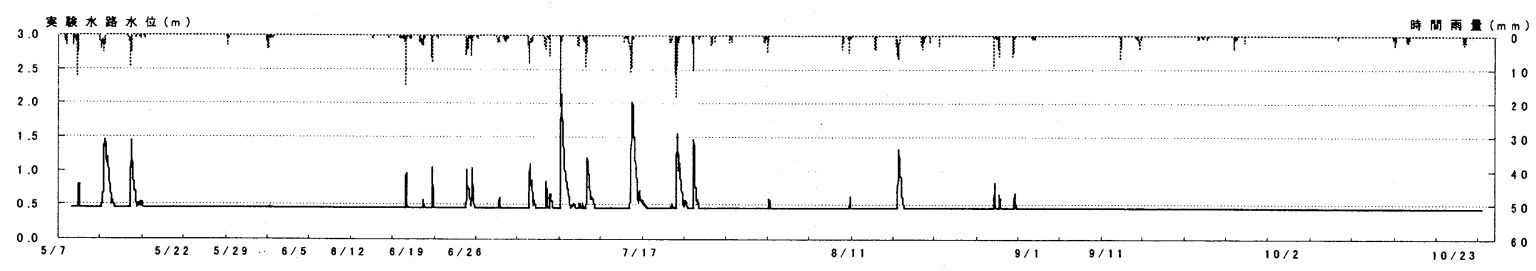

図-4 実験水路水位(左軸)と雨量観測データ(右軸)
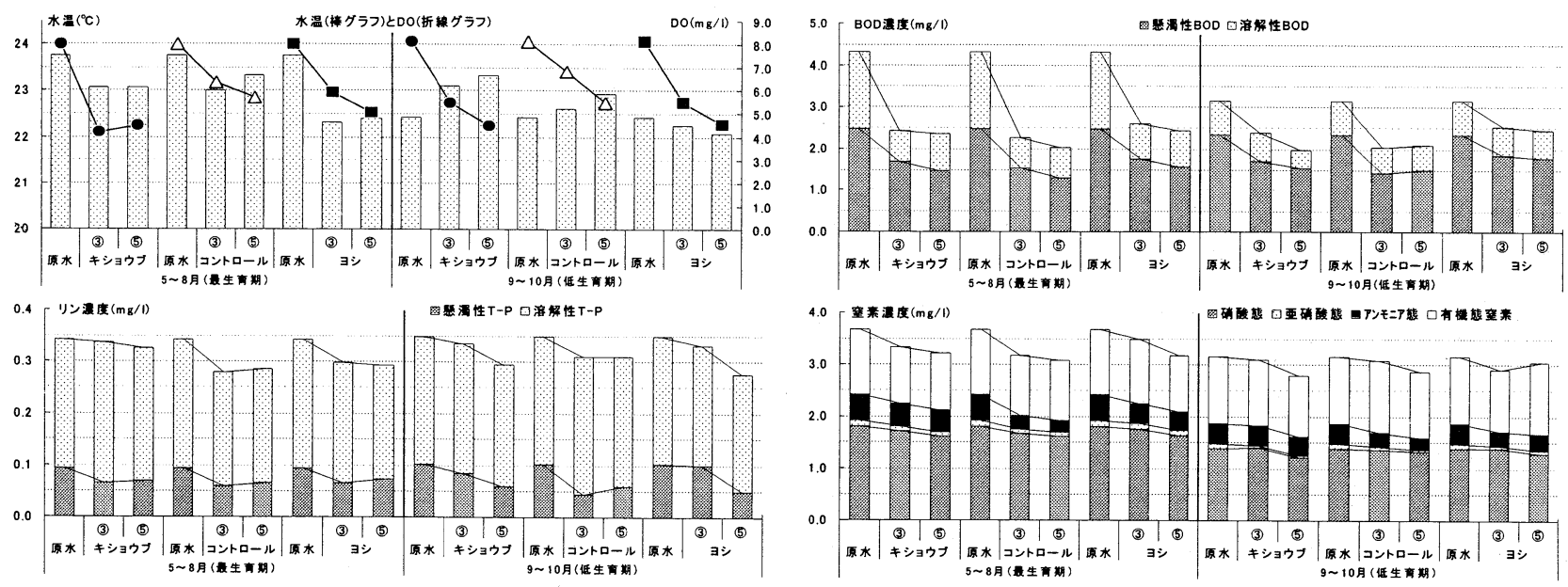

図-5 水温、DO、BOD、T-N、T-P の各期の場所別平均濃度值

1 時間ずつが 3 回、 7 月は 1 時間、 12 時間、 6 時間、 16 時間、 13 時間、そして 5 時間の 6 回、8 月は 5 時間が 1 回であった。9月と 10 月は無冠水であった。

\section{4. 結果および考察}

\section{（1）水質項目の結果}

図-5には各水質項目の観測・分析結果を最生育期と低 生育期に分け、場所別平均值で示す。

水温は水路流下によって最生育期はキショウブ水路と コントロール水路は顥著な低下はないが、ヨシ水路は他 水路に比べ低下割合が高い。低生育期は水路流下により キショウブ水路とコントロール水路は増加するが、ヨシ 水路は低下していた。よってヨシ水路けヨシによる遮光 効果により他の水路より水温が低いと考えられる。

DO は両期とも水路流下とともに減少傾向であり、最 生育期はキショウブ水路の減少量が大きく、低生育期は キショウブ水路とヨシ水路の減少量が大きかった。これ は、キショウブ水路はポンツーンが、ヨシ水路はヨシが 各ブロックで光遮蔽することで付着藻類や植物プランク トンの棲息空間を制限し、光合成抑制により酸素供給が 少ないためと考えられる。逆にコントロール水路では光 遮蔽することなく、生物体の酸素供給が活発であったと 考えられる。

BOD は両期とも全測点で $6 〜 7$ 割が懸濁成分である。 各期の水路流下にともない濃度減少が大きいのは 3 水路 とも最生育期は溶解成分、低生育期は眯濁成分であった。 原水から最下流測点までの除去量が大きいのは、最生育
期はコントロール水路、低生育期はキショウブ水路であ つた。

$\mathrm{T}-\mathrm{N}$ は両期とも全測点の T-N 成分は硝酸態窒素が全体 の 4〜5 割であり、無機態成分は 6〜 7 割と高い。原水か ら最下流測点までの除去量が大きいのは、最生育期はコ ントロール水路、低生育期はキショウブ水路であった。

BOD と T-N は最生育期において、キショウブ水路や ヨシ水路などの植栽水路より、無植栽のコントロール水 路の方が除去率は高い。この要因としては、植栽水路は コントロール水路に比べて嫌気した底泥、腐敗した植物、 植物プランクトンなど内部生産物の流出などによる系へ の回帰などが多いと考えられる。

$\mathrm{T}-\mathrm{P}$ 成分は T-N と同様に両期とも全測点で 7〜8 割が 溶解成分である。T-P の原水から最下流測点までの濃度 減少が大きいのは最生育期ではコントロール水路とヨシ 水路、低生育期ではヨシ水路であった。ヨシ水路の濃度 減少が大きいのは懸濁成分の沈降とともに、他水路に比 べ溶解成分の植物吸収や土壌への吸着が大きいためと推 察できる。

\section{（2）生物項目の結果}

生物相は河川出水の影響を大きく受ける。各生物調査 日は、水路冠水状態(水位 $1 \mathrm{~m}$ 以上)から 6 月調査と 8 月調 查は 20 日後、10月調査は 68 日後であるので比較的安定 した時の調査といえる。

微生物体内の典型的な窒素/リン構成比を表す Redfield 比は 7.24)であり、実験水路の T-N/T-P 重量比は平均 10.4 であることから、リン制約の環境下にあるといえる。

また各調査日の水温は、各測点間の水温差はあまりな 


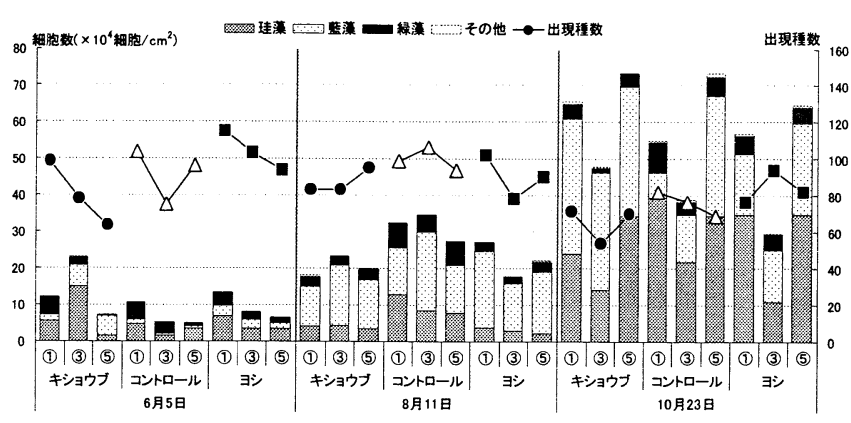

図-6 付着藻類の密度数(棒グラフ)と出現種数(折線グラフ $)$

いことから、ここでは原水の水温を示す。 6 月が $23.5^{\circ} \mathrm{C}$ 、 8 月が $26.9^{\circ} \mathrm{C} 、 10$ 月が $15.9^{\circ} \mathrm{C}$ であり、一般的に多くの植 物プランクトンの最適増殖水温は $18 \sim 25^{\circ} \mathrm{C}$ であるから、 最適増殖水温より 8 月は若干高く、10月は若干低かった。 生物調查により各測点毎への棲み分けや水質浄化との 関係を調查するため次式(1)〜(2)の指数を用いて論ずる。

式(1)は各群集の種数と個体数を考慮した Kimoto(1967) 5)の群集類似度指数 $C \pi$ であり、各水路内の上·下流測点 や水路相違などの位置的相違を群集構造の類似性により 各測点間を比較する。

$$
\begin{gathered}
C_{\pi}=\frac{2 \sum_{i=1}^{s} n_{1 \mathrm{ii}} \times n_{2 \mathrm{i}}}{\left(\sum \pi_{1}{ }^{2}+\sum \pi_{2}{ }^{2}\right) N_{1} \cdot N_{2}} \quad 0 \leq C_{\pi} \leq 1 \\
\sum \pi_{1}^{2}=\frac{\sum_{i=1}^{s} n_{1 i}^{2}}{N_{1}{ }^{2}} \quad \sum \pi_{2}^{2}=\frac{\sum_{i=1}^{s} n_{2 i}^{2}}{N_{2}^{2}}
\end{gathered}
$$

$N_{1} 、 N_{2}$ : 各サンプルの総個体数、 $n_{1 \mathrm{i}} 、 n_{2 \mathrm{i}}$ : 各サンプルの各 種の個体数、2 測点間の共通種が多い程 $C \pi$ は 1 に近づく。 式(2)は指標種による生物学的水質污濁を求める式であ る。(Pantle $\cdot$ Buck 法 $)^{6}$

$$
P I=\frac{\sum(s \times h)}{\sum h}
$$

$h$ :出現個体数、 $\mathrm{s}$ :污濁階級指数

\section{a) 密度数 - 出現種数 - 優占種}

図-6に付着藻類の密度数と出現種数を示す。

付着藻類の密度数は単位面積当りの細胞数であり、6 月が 5.1 万〜 23.1 万細胞 $/ \mathrm{cm}^{2} 、 8$ 月が 17.7 万〜 34.8 万細 胞 $/ \mathrm{cm}^{2} 、 10$ 月が 29.8 万〜 73.6 万細胞/ $\mathrm{cm}^{2}$ であり、全 9 測点で 6 月、 8 月、 10 月へと経時的に増加傾向にある。 出現種数は、 6 月が $64 \sim 115$ 種、8 月が 78〜106 種、 10 月が 54〜94 種であり、全体的に 6 月が多く、次いで 8月、10月の順に経時変化とともに低下傾向にある。

優占綱を各調查日毎に示すと、出現種数は全調査日・全 測点で珪藻綱が全体の 6〜7割を占めていた。しかし密度 数は6月が珪藻綱、藍藻綱、そして緑藻綱、8月が藍藻 綱だけ、10月が珪藻綱と藍藻綱であり、6月と 10 月は各 測点で優占綱の相違があるが、8月は相違は認められない。

ここで各調査日の密度数が一番高い優占種 1 位は、6 月は緑藻綱の Scenedesmus armatus や Scenedesmus quadricauda、藍藻綱 Homoeothrix varians など、8 月

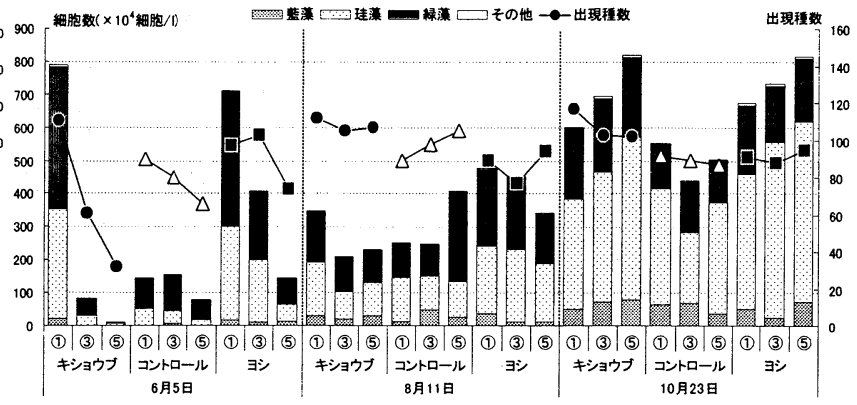

図-7 植物プランクトンの密度数(棒グラフ)と出現種数(折線グラフ)

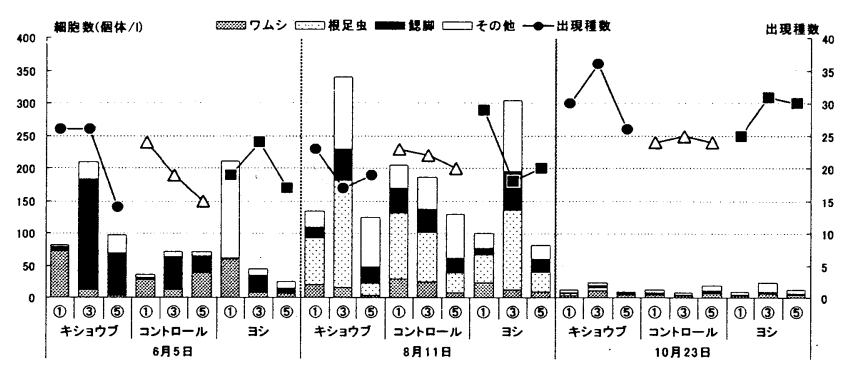

図-8 動物プランクトンの密度数(棒グラフ)と出現種数(折線グラフ)

は全測点で藍藻綱 Homoeothrix varians、10 月は藍藻綱 Homoeothrix varians、珪藻綱の Nitzschia amphibiaや Nitzschia palea であり、藍藻綱 Homoeothrix varians は各調查日で優占種 1 位になっていた。

図-7に植物プランクトンの密度数と出現種数を示す。

植物プランクトンの密度数は単位体積当りの細胞数で あり、6 月が 10.1 万〜 714.6 万細胞/ 476.7 万細胞/ 1 、10月が 438.8 万〜 818.7 万細胞/どあり、 6 月のキシュブ水路内とヨシ水路内の測点間に顕著な密 度差があるが、経時的には付着藻類の密度数と同様にほ ぼ各測点において 6 月、 8 月、10 月の順に密度数は高く なり、特に 8 月から 10 月への増加が顕著に表れている。

出現種数は 6 月が $32 \sim 111$ 種、 8 月が $79 \sim 116$ 種、 10 月が $87 \sim 117$ 種であり、 6 月は各水路内の種数の差が大 きいが、10月では種数の差は小さい。

優占綱を各調査日毎に示すと、出現種数は 6 月のコン トロール水路全 3 測点とヨシ水路測点(5)、8 月のヨシ水 路測点(1)では緑藻綱が優占綱であったが、それ以外は珪 藻綱が優占綱であった。密度数は 6 月がキシュブ水路測 点(5)だけが珪藻綱であり、他の測点は緑藻綱である。8 月はキショウブ水路測点(3、コントロール測点(5)、ヨシ 水路測点測点(3) と(5)が珪藻綱であり、他の測点は緑藻綱 である。10月は全測点珠藻綱であった。

各調査日の密度数が一番高い優占種 1 位は、 6 月は珪 藻綱 Cyclotella meneghiniana や緑藻綱 Coelastrum sphaerioum、Scenedesmus armatus であり、8 月と 10 月は全測点で珪藻綱Cyclotella meneghinianaであった。

図-8に動物プランクトンの密度数と出現種数を示す。

動物プランクトンの密度数は単位体積当りの個体数で あり、6 月が $24.2 \sim 211.2$ 個体/ $/$ 、8 月が 81.2 304.0 個 
表-1 付着薬類の類似度指数マトリックス

\begin{tabular}{|c|c|c|c|c|c|c|c|c|c|c|c|c|c|c|c|c|c|c|c|c|c|c|c|c|c|c|c|c|c|c|c|c|}
\hline \multirow{2}{*}{\multicolumn{2}{|c|}{ 6月 }} & \multicolumn{3}{|c|}{ キショウブ水路 } & \multicolumn{3}{|c|}{ コントロール水路 } & \multicolumn{3}{|c|}{ 寻涾路 } & \multirow{2}{*}{\multicolumn{2}{|c|}{ 8月 }} & \multicolumn{3}{|c|}{ キショウフ水路 } & \multicolumn{3}{|c|}{ コントロール水路 } & \multicolumn{3}{|c|}{ 寻涾路 } & \multirow{2}{*}{\multicolumn{2}{|c|}{ 10月 }} & \multicolumn{3}{|c|}{ キショウフフ水路 } & \multicolumn{3}{|c|}{ コントロール水路 } & \multicolumn{3}{|c|}{ 羿水路 } \\
\hline & & (1) & (3) & (5) & (1) & (3) & (5) & (1) & (3) & (5) & & & (1) & \multicolumn{2}{|c|}{ (3) (5) } & (1) & (3) & \multirow[t]{2}{*}{ (5) } & (1) & \multicolumn{2}{|c|}{ (3) (5) } & & & (1) & (3) & (5) & (1) & (3) & (5) & (1) & (3) & (5) \\
\hline キシ & (1) & 1 & & & & & & & & & \multirow{3}{*}{$\begin{array}{c}\text { キショウブ } \\
\text { 水路 }\end{array}$} & (1) & 1 & & & & & & & & (5) & \multirow{3}{*}{\begin{tabular}{|c|}
$\begin{array}{c}\text { キショウブ } \\
\text { 水路 }\end{array}$ \\
\end{tabular}} & (1) & 1. & & & & & & & & \\
\hline \multirow[t]{2}{*}{ 水趾 } & (3) & 0.58 & 1 & & & & & & & & & (3) & 0.94 & 1. & & & & & & & & & (3) & 0.92 & 1 & & & & & & & \\
\hline & (5) & 0.18 & 0.55 & 1 & & & & & & & & (5) & 0.92 & 0.88 & 1 & & & & & & & & (5) & 0.94 & 0.90 & 1 & & & & & & \\
\hline \multirow{3}{*}{$\begin{array}{c}\text { エントロール } \\
\text { 水路 }\end{array}$} & (1) & 0.85 & 0.46 & 0.05 & 1 & & & & & & \multirow{3}{*}{$\begin{array}{c}\text { コントロール } \\
\text { 水路 }\end{array}$} & (1) & \begin{tabular}{|l|}
0.65 \\
\end{tabular} & 0.70 & 0.56 & 1 & & & & & & \multirow{3}{*}{$\begin{array}{c}\text { コントロール } \\
\text { 水路 }\end{array}$} & (1) & 0.25 & 0.12 & 0.33 & 14 & & & & & \\
\hline & (3) & 0.79 & 0.49 & 0.19 & 0.83 & 1 & & & & & & (3) & 0.89 & 0.82 & 0.99 & 0.49 & 1 & & & & & & (3) & 0.42 & 0.28 & 0.49 & 0.75 & & & & & \\
\hline & (5) & 0.61 & 0.56 & 0.07 & 0.76 & 0.56 & 4 & & & & & (5) & 0.95 & 0.88 & 0.91 & 0.66 & 0.89 & 1 & & & & & (5) & 0.92 & 0.86 & 0.94 & 0.36 & 0.49 & 1 & & & \\
\hline \multirow{3}{*}{$\begin{array}{l}\text { 沝 } \\
\text { 路 }\end{array}$} & (1) & 0.71 & 0.78 & 0.37 & 0.66 & 0.54 & 0.72 & 1 & & & $\exists シ$ & (1) & 0.84 & 0.77 & 0.96 & 0.44 & 0.98 & 0.83 & 1 & & & & (1) & 0.61 & 0.42 & 0.60 & 0.69 & \begin{tabular}{|l|}
0.54 \\
\end{tabular} & 0.61 & 4 & & \\
\hline & (3) & 0.51 & 0.79 & 0.55 & 0.48 & 0.46 & 0.47 & 0.84 & 1 & & 水路 & (3) & 0.92 & 0.87 & 0.98 & 0.51 & 0.97 & 0.90 & 0.97 & 1 & & 水路 & (3) & 0.81 & 0.62 & 0.76 & 0.49 & 0.59 & 0.77 & 0.79 & 4 & \\
\hline & (5) & 0.60 & 0.84 & 0.50 & 0.53 & 0.53 & 0.66 & 0.91 & 0.90 & 1 & & (5) & 0.92 & 0.94 & 0.87 & 0.51 & 0.83 & 0.83 & 0.81 & 0.91 & & & (5) & 0.59 & 0.38 & 0.59 & 0.53 & \begin{tabular}{|l|}
0.53 \\
\end{tabular} & \begin{tabular}{|l|}
0.62 \\
\end{tabular} & 0.78 & 0.81 & \\
\hline
\end{tabular}

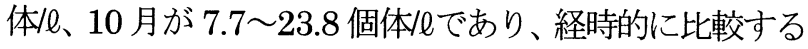
と、6月から 8 月へは増加傾向を示寸が、8月から 10 月 へは大幅に減少している。

出現種数は 6 月が $14 \sim 26$ 種、 8 月が $17 \sim 29$ 種、 10 月が $24 \sim 36$ 種であり、全体的に 10 月の種数が多い。

各調查日の密度数が一番高い優占種 1 位は 6 月がワム シ綱 Brachionus calyciflorusf. anuraeiformis、貧膜口綱 Epistylis sp、、鰓脚綱 Bosmina longirostris 等であり、8 月は根足虫綱 Centropyxis aculeata P Centropyxis sp. アゴアシ綱の Copepodid of Cyclopoida や Nauplius of Copepoda 等であり、10 月はキネトフラグミノフォーラ 綱 Suctorida sp.、アゴアシ綱 Nauplius of Copepodaや Copepodid of Cyclopoida 等であり、各調查日でも各測点 において優占種 1 位に大きな相違がみられる。

以上より付着藻類と植物プランクトンの密度数は 6 月 から 10 月へと増加傾向にあるが、逆に動物プランクトン の密度数は 6 月から 8 月へは増加傾向を示すが、 8 月か ら 10 月へは大きく減少傾向を示している。付着藻類、植 物プランクトン、および動物プランクトンの各生物群集 の密度数に影響を及ぼす環境条件は、主に水温、有機物、 栄養塩類などの水質、流速(滞留時間)、そして付着藻類と 植物プランクトンは動物プランクトン、魚類、底生動物 と捕食と被食の関係にある。またこれ以外に付着藻類と 植物プランクトンには光条件や、付着藻類は付着基盤の 種類・サイズや基盤面の位置の影響も受ける。

一般的には動物プランクトンの減少は、種固有の季節 性(生活史)、被食者(餌)、水温などの環境要因、そして捕 食者による捕食の影響を受ける。本調査においては被食 者(餌)となる付着藻類や植物プランクトンの 10 月の密度 数が最も高いことから、動物プランクトンの減少は水温 の低下による季節的な環境要因が大きいと考えられる。 よって動物プランクトンの 10 月の密度数が少ないため に、逆に付着藻類や植物プランクトンの 10 月の密度数は 多くなったと考えられる。

また付着藻類は、6月から 10 月へと密度数は増加傾向 にあるが、逆に出現種数は全体的に低下傾向にある。よ って群集構造は経時変化とともに単純化する傾向にある ことがわかる。また総出現種数は全調査ともヨシ水路の 種数が多く、キショウブ水路の種数が少ないことから、3 水路のうちキショウブ水路内の環境が早くから安定化す る傾向にあるものと考えられる。
本実験において付着基盤の種類・サイズや基盤面の位 置、光条件については、各調查測点は開水路部であり、 また付着藻類の各採取場所は同じ石垣面で、ほぼ同じ水 深であるからあまり影響要因とは考えられない。また各 水路の採水·調查測点の流速は約 $5.6 \mathrm{~cm} / \mathrm{min}$ ( ヨシの植栽 部では約 $28.3 \mathrm{~cm} / \mathrm{min}$ ) と非常に緩流から微流であり、こ のことが生物体に大きな影響を与えているとは考えにく い。ちなみに各水路の最上流部から最下流までの滞留時 間はキショウブ水路とコントロール水路が約 16 時間、ヨ シ水路が約 6 時間とヨシ水路はキショウブ水路とコント ロール水路に比べ滞留時間が短い。よって、これ以外の 要因が各測点での密度数・出現種数に影響を及ぼすと考 えられるが、この要因については今後の課題である。

\section{b) 類似度指数}

表 -1 に付着藻類の各調査日毎の類似度指数マトリック スを示す。各調査日の全 36 測点間のうち、 $C \pi>0.70$ は 6 月が 12 測点間、 8 月は 29 測点間、 10 月は 13 測点間 である。これより 8 月の類似度の高い測点間が非常に多 いことから、水路相違や位置的相違はなく種構成は同種 から構成されている。しかし 6 月と 10 月では、6月はコ ントロール水路とヨシ水路、10月はキショウブ水路とヨ シ水路のそれぞれ同じ水路内の測点間の類似度が高いが、 他の水路測点間では類似度が低いことからそれぞれの水 路内での種構成に相違があることがわかる。

植物プランクトンと動物プランクトンの類似度指数マ: トリックスの表は紙面の都合上割愛する。

植物プランクトンについては各調査日の全 36 測点間 のうち、 $C \pi>0.70$ は 6 月が 26 測点間、 8 月は 33 測点間、

10 月は 36 測点間である。これより 10 月の類似度の高い 測点間が非常に多く、またその他の調査日についても類 似度が高いことから、植物プランクトンは付着藻類より も水路相違や位置的相違はなく種構成は同種から構成さ れている。

最後に動物プランクトンの各調査日の全 36 測点間の うち、 $C \pi>0.70$ は 6 月が 3 測点間、 8 月は 25 測点間、 10 月は 15 測点間である。これより 8 月においてはコン トロール水路とヨシ水路の全 $\mathbf{9}$ 測点間のうち 8 測点が $C$ $\pi>0.70$ と水路相違する測点間でも種構成はほぼ同種か ら構成されているものの、動物プランクトンは付着藻類 や植物プランクトンに比べ、全体的に各調査日において 各測点での種構成に相違があることがわかる。 


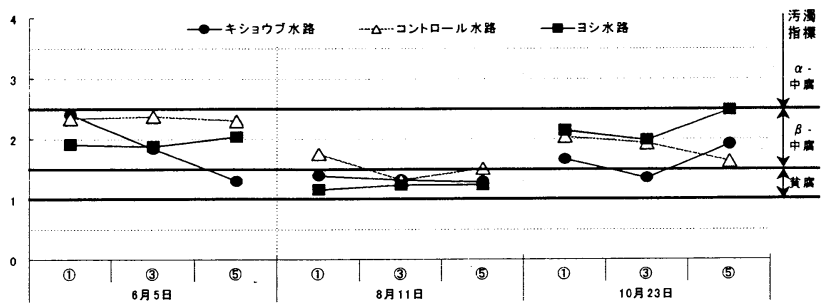

図-9 付着藻類による污濁指標(PI)

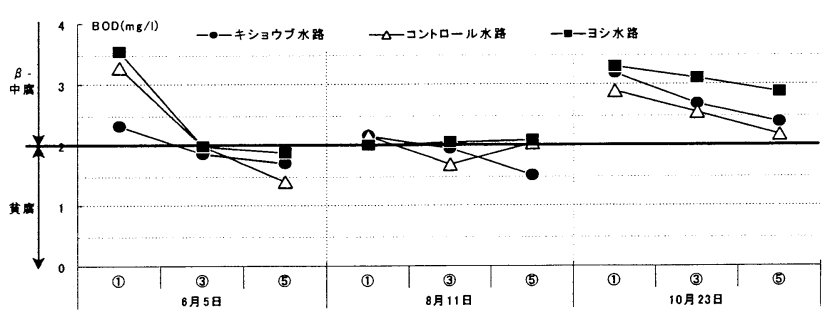

図-11 BODによる污濁区分

\section{c）付着藻類と植物プランクトンによる污濁判定 ${ }^{8)}$}

Pantle•Buck 法により指標種による污濁指標を、付着 藻類は図-9 に、植物プランクトンは図-10 に示す。また 各調査日の BOD による污濁判定を図-11 に示寸。BOD による判定は 6 月が測点(1)で $\beta$ 中腐水性 $\alpha$ 中腐水性、 他の測点は $\beta$ 中腐水性であり、8 月はほぼ貧腐水性、10 月は $\beta$ 中腐水性であった。付着藻類による判定は 6 月が $\beta$ 中腐水性、 8 月がほぼ貧腐水性、10 月がほぼ $\beta$ 中腐水 性であった。植物プランクトンによる污濁判定は 6 月が $\beta$ 中腐水性 $\sim \alpha$ 中腐水性、 8 月と 10 月が $\beta$ 中腐水性であ った。したがって付着藻類、植物プランクトンによる污 濁判定と BODによる污濁判定とはほぼ一致していた。

\section{d) 付着藻類の種組成}

付着藻類の定着·繁茂する過程は、初期段階では細菌の 被膜が形成された後、平面的に付着する珪㩰綱が出現し、 辰い柄で付着する珪藻綱や、ロヤ゙ット状に呈する珪藻綱、 さらに糸状性の緑藻綱や藍藻綱が主体の立体的な構造の 群集へと遷移する7)。図-12 に付着藻類の各調査日の密度 数に基づく系状性藻類の割合を示す。これよりほぼ 8 月 の糸状性藻類の割合が高いことがわかる。糸状性藻類の 多くは優占種 1 位であった藍藻綱 Homoeothrix varians である。よってこの種が 8 月に水路相違なく全測点で優 占種 1 位であった要因としては、 6 月と 8 月の調査はと もに河川出水後 20 日後であり、出水からの時間経過が同 じであるから、主に水温などの影響により 8 月の系状性 藻類が高密度となったと推察できる。しかし水路別では、 優占率はヨシ水路での占有率が高く、コントロール水路 が低い結果となったが、この水路相違については他の要 因が考えられるが、その点については今後の課題である。

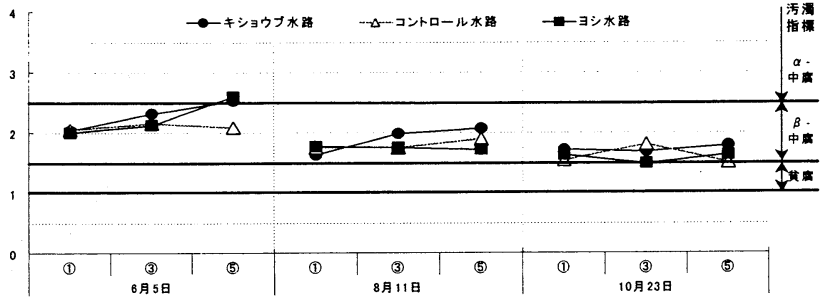

図-10 植物プランクトンによる污濁指標(PI)

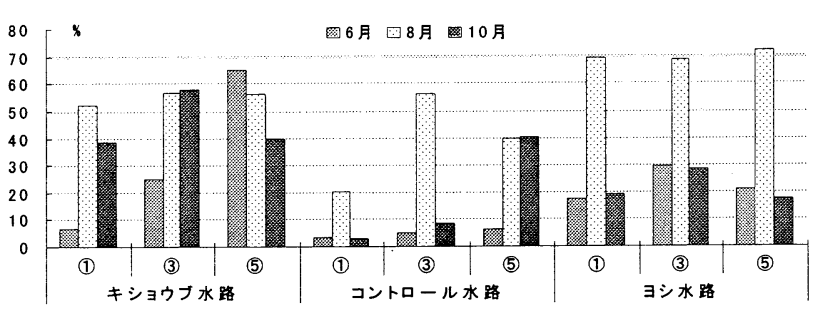

図-12 付着藻類の系状性藻類の割合

ショウブ水路であり、T-P は最生育期、低生育期ともに ヨシ水路であった。

(2). 種構成の類似性についてみると、植物プランクトンは 6 月、 8 月、 10 月の 3 調査とも各水路内での位置的相違 や水路相違はなく種構成は非常に類似している。付着藻 類と動物プランクトンについては、8月において各水路内 での位置的相違や水路相違はなく種構成が類似していた。 (3). 付着藻類、植物プランクトンによる污濁判定と BOD による污濁判定とはほぼ一致していた。

\section{参考文献}

1）島谷幸宏、細見正明、中村圭吾 : エコテクノロジーによる河 川・湖沼の水質浄化、ソフトサイエンス社、pp.148-162、2003.

2）（財)河川環境管理財団(2002) : 植生浄化施設計画の技術資料、 河川環境総合研究所資料第 5 号、平成 14 年 12 月.

3）東京都水産試験、平成 11 年度主要技術成果集「植物栽培によ る養殖排水の浄化」、1999.

4）楠田哲也編著 : 自然の浄化機構の強化と制御、技報堂出版、 1994.

5）木元新作、武田博清 : 群集生態学入門、共立出版、1989.

6）玉井信行、水野信彦、中村俊六 : 河川生態環境工学、東京大 学出版、1993.

7）アレキサンダー・J・ホーン、チャールズ・R・ゴールドマン著、 手塚泰彦訳 : 陸水学、京都大学学術出版会、1999.

8）津田将行: 強污濁河川の水質浄化現地実験とその浄化効果の 総合評価に関する研究、福山大学博士論文、2004.

(2004.9.30 受付)

\section{5. まとめ}

本研究より得られた知見は以下にようである。

(1).各水質項目について净化効果が大きいのは、BOD、

$\mathrm{T}-\mathrm{N}$ は最生育期ではコントロール水路、低生育期ではキ 